\title{
ENERGY, ULTRASOUND, AND CHEMICAL TREATMENTS FOR THE DISINFESTATION OF FRESH ASPARAGUS SPEARS
}

\author{
C.W. VAN EPENHUIJSEN, J.P. KOOLAARD and J.F. POTTER
}

\author{
New Zealand Institute for Crop \& Food Research Limited \\ Levin Research Centre, Private Bag 4005, Levin
}

\begin{abstract}
Low level electrical energy (alternating and direct current), high voltage pulses from two energisers, and ultrasound were assessed for their ability to kill insects, or expel them from asparagus spears. Spears were held in an electrolyte solution containing $0.12 \%(\mathrm{w} / \mathrm{v})$ sodium chloride in water during the treatments. Electrical treatments lasted for 2, 4, or 8 minutes. A second experiment was used to test three chemical treatments applied for 8 minutes. None of the electrical and ultrasound treatments killed or expelled significantly more insects than the untreated controls in water or sodium chloride $0.12 \%(\mathrm{w} / \mathrm{v})$. A new chemical, Y-14258, expelled and killed significantly more thrips than the other chemical treatments and control.
\end{abstract}

Keywords: asparagus, disinfestation, electrical current, energiser, thrips, ultrasound.

\section{INTRODUCTION}

Insect infestation in asparagus spears involves mainly thrips, but the variety of insects depends on the different weeds in the plot or in surrounding vegetation (Watson and Townsend 1981). The thrips species most commonly found in asparagus spears are Thrips tabaci and Apterothrips apteris, formerly Apterothrips secticornis (van Epenhuijsen and Wright 1994).

Disinfestation of fresh asparagus spears is required for export of fresh asparagus from New Zealand to markets with strict quarantine regulations. Methods for asparagus disinfestation were sometimes ineffective (van Epenhuijsen and Wright 1994), resulted in unacceptable residues (Carpenter 1987) or affected the firmness of spears (Rohitha et al. 1992). Oils and maldison affected the smell and appearance of spears after treatments (Waller 1990). Elevated carbon dioxide treatments may cause some offflavours and affect shelf life (Corrigan and Carpenter 1993; Carpenter 1995). Stem collapse and browning of the bract has been found in some controlled atmosphere treatments (Carpenter 1995).

Penetration of liquids into air pockets under the bracts is a major problem when applying disinfestation treatments in solution to asparagus. Water retention- reducing liquids, such as organo-silicone copolymer penetrants, and surface-active agents such as Pulse penetrant and saponified fatty acids enabled penetration of air pockets (Rohithaet al. 1992; van Epenhuijsen and Wright 1994). Thrips were killed or expelled from the spears using these chemicals. Expelling insects from the spears is preferred by the canneries, because they have obvious problems when dead thrips are found floating in the brine after canning.

The creation of micropores in the cell membrane by exposing living cells suspended in an aqueous solution to a pulsed electric field is used in electroporation which has been used to successfully sterilise a continuous flow of liquid, killing bacteria and other microorganisms (Johnstone and Bodger 1996). Some literature is available on the effects of electric shocks on insects (Sharma and Singh 1994; Pickens et al. 1994; Watson and Townsend 1981).

Electric fence energisers produce a short, high voltage pulse at a rate of about one pulse per second for one thousandth of a second. In a laboratory controlled electric field,

Proc. 50th N.Z. Plant Protection Conf. 1997: 436-441 
earthworms became agitated and moved away from an energised conductor (Jamieson and Bodger 1988). Treatments with ultrasonic waves were found to successfully control Sitophilus granarius adults inside the grain when wheat grains were treated for $2.5 \mathrm{~min}$ at about $5.4 \mathrm{~W} / \mathrm{cm}^{2}$ (Pradzynska 1982). Even though there is a desire to use chemicalfree products, microwave energy and radio-frequency have so far not found their way into practical disinfestation treatments (Nelson 1996).

This work forms part of an on-going programme to investigate methods for disinfesting horticultural crops that are washed before being exported. Electrical methods seem, in principle, to satisfy the philosophy of low expense and low residue.

In this project we aimed to determine the feasibility of electrical energy and ultrasound in a disinfestation system. The effectiveness of these novel methods was subsequently compared with chemical methods in a second experiment.

\section{MATERIALS AND METHODS}

Twenty-four electrical, six ultrasound and two control treatments (Table 1), were carried out in seven randomised incomplete blocks, over a period of seven days from 13 November 1996, each day representing a block. In total, three replicates with 15 spears in each treatment were made. A second experiment to confirm the efficacy of a previously tested chemical treatment was carried out in a completely randomised experimental design in March 1997. Three replications of each treatment were applied in random order on the same day. A control treatment with spears held in de-ionised water, was included. All harvested asparagus spears $(180 \mathrm{~mm})$ were bagged in nylon mesh, closed with a rubber band and placed in a plastic water bath containing 6.5 litres de-ionised water with or without $0.12 \%$ (w/v) sodium chloride. This solution provides a low voltage and does not damage the spears. The electrolyte solution was replaced after each replicate.

Carbon fibre electrodes were placed at opposite ends of the water bath, energized with alternating current (AC) or direct current (DC) of 0.5, 1.5 and 2.5 amperes.

Complete spears were checked for the presence of insects. Recent research has shown that this laborious job could be made easier by examining the top $75 \mathrm{~mm}$ only, where $70 \%$ of live thrips are found (van Epenhuijsen unpubl. data).

\section{Treatment bath}

Electrodes were made from 190 x $110 \mathrm{~mm}$ carbon fibre cloth (Style: CC195 cloth, High Modulus NZLtd, Auckland) attached to a galvanised frame with a plastic strip on the inside and fixed together with nylon bolts and nuts. In order to avoid electrolysis, a piece of platinum wire connected the fibre cloth to sockets which were in turn attached to the electrodes.

All electrodes had two round holes (diameter $9 \mathrm{~mm}$ ) in the top, $165 \mathrm{~mm}$ apart. Glass fibre rods were inserted into these holes so that the distance between the electrodes could be altered simply by sliding them along the rods. Notches in a wooden frame on top of the treatment bath kept the rods in place.

An electrical current was also produced by two energisers $(4.5$ or $7.8 \mathrm{kV})$ and two ultrasound generators ( 100 and $200 \mathrm{~W}$ treatments) were also tested. The treatments were applied to three replicates of 15 spears and lasted for 2,4 or 8 minutes. Chemical treatments were for 8 minutes only. Reusable ice packs were used to keep the temperature at about $20^{\circ} \mathrm{C}$ as some treatments raised the temperature of the electrolyte solution.

\section{Ultra sound}

The two instruments used are designed for the sonication of samples which are liquid, or immersed in water. A 100 Watt Sonicor SC120 ultrasonic cleaner (Sonicor Instrument Corporation, USA) contained 2.6 litres of de-ionised water. The Probe of the Braun 1000L was set at high 200 $\pm 10 \mathrm{Watt}$ and was immersed $15 \mathrm{~mm}$ in a stainless steel container which contained 6.5 litre of de-ionised water.

\section{Energisers}

Two energisers were used; an M800 Gallagher power fence energiser ( $7.8 \mathrm{kV}$ output on high setting, pulse interval 1.10 second, pulse width 350 microsecond, pulse shape approximately $1 / 2$ sine wave) and a $9 \mathrm{~V}$ battery-operated Speedrite energiser with an output of 4.5-5000 V on fast setting (pulse interval $1.2 \mathrm{sec}$., pulse width approximately 
30 microseconds and pulse shape of $1 / 2$ sine wave). Peak voltages were measured with a hand held digital voltmeter. Electrodes for the energisers were made from a $1900 \mathrm{x}$ $1000 \mathrm{~mm}$ stainless plate.

\section{AC circuit}

The AC circuit consisted of a plastic box with an AC voltmeter (0-300 V) and an AC Ammeter (0-5A). The DC circuit consisted of a voltmeter (0-300 V), an Ammeter (0$5 \mathrm{~A})$, a $400 \mathrm{~V}-6 \mathrm{~A}$ bridge rectifier, and a smoothing capacitor $(200 \mu \mathrm{F}, 400 \mathrm{~V})$. In both circuits, banana plugs were fitted to the end of the wires. The currents were set with a Variac (variable output transformer) output 0-270 V / 6 A, and an isolating transformer was used for safety reasons. All the bags containing spears were submerged in the liquids at right angles to the electrodes. In order to submerge the bags of spears, a weighted plastic grid was placed on top of them. The current was controlled with a variable output transformer, and kept as close to the target current as possible, for a current of 0.5 amperes DC voltage between 25-50 V, for $1.5 \mathrm{~A}(70-90 \mathrm{~V})$ and $2.5 \mathrm{~A}(120-140 \mathrm{~V})$. For the AC treatments at $0.5 \mathrm{~A}$, voltage varied between $40-50 \mathrm{~V}$, for $1.5 \mathrm{~A}(70-100 \mathrm{~V})$, and for $2.5 \mathrm{~A}(120-160 \mathrm{~V})$ (Table 1).

After the treatments, the spears and bags were washed above a funnel with a fine sieve, and dead and live thrips and nymphs were collected and counted. Spears were then stored overnight at $1.0^{\circ} \mathrm{C}$. Spear tips (top $75 \mathrm{~mm}$ ) were checked for insects; all buds and bracts were removed with a scalpel, and examined under a stereo microscope.

\section{Chemical treatments}

Three chemicals, an experimental one, called Y-14258 $0.1 \%$ (v/v ) a Witco osi penetrant from the USA, Veggi-wash $0.05 \%(\mathrm{v} / \mathrm{v})$, a proprietary mix of natural plant oils, and Defender $0.1 \%$ (v/v ), a saponified fatty acid, were tested for their abilities to kill or expel thrips after 8 minutes exposure.

After treatments, the expansion zones ( $75 \mathrm{~mm}$ ) of the asparagus spears were checked for dead and live insects. All insects expelled from the spears during the treatment were also collected from the organza bags and counted.

\section{Data analysis}

Number of thrips and nymphs (out of the total number) expelled from the spears after treatment and the number of thrips and nymphs found dead in the spears after treatment out of the total number found in the spears were recorded. Both these measurements were analysed using a generalised linear model with a logit link function and a binomial error structure. This means that the logit transformation of the response proportions (of expelled and dead insects) is assumed to be linearly dependent on the treatments, and that the two measurements of interest (above) are assumed to follow a binomial distribution. For the experiment involving the electrical treatments, the block structure could be ignored since the variation between days (blocks) was found to be negligible. Thus both experiments were analysed in the same way.

Predicted means from the model for the response proportions (expelled and killed) for each treatment were calculated together with $95 \%$ confidence intervals. All analyses were carried out using Genstat (1993).

\section{RESULTS}

Of all the pests recorded, $99.4 \%$ were thrips. Of all the adult thrips, $92.1 \%$ were Thrips tabaci, $7.6 \%$ were Apterothrips apteris and $0.2 \%$ were unidentified thrips species. Out of the total of thrips and nymphs, $10 \%$ were nymphs. On average, there were 1.4 thrips and nymphs dead or alive per $75 \mathrm{~mm}$ spear in the first experiment and an average of 15.4 adults and nymphs dead or alive per $75 \mathrm{~mm}$ spear in the second experiment. This latter experiment was carried out after the season had closed, and the very few spears present were infested by large numbers of thrips. Electrolysis together with some brown discolouring of the water in the DC voltage treatments occurred, but this did not affect spear quality.

In the first experiment, the treatments expelled few thrips from the spears, less than $10 \%$ for most of the treatments which was no different from the controls (Table 1). Only three alternating current treatments (1.5 A for 2 and 8 minutes and $2.5 \mathrm{~A}$ for 2 minutes) expelled between 12.5 and $23.2 \%$. No shelf-life assessment of the asparagus was carried 
out, but treatments were chosen so that no visible damage was seen by the heat generated from the electric currents or the chemicals within one day of treatment.

TABLE 1: Experiment 1(November 1996). Treatments in de-ionised water used in the disinfestation of asparagus spears with or without sodium-chloride. Duration of treatment, current (A) and voltage (V) measurements. Predicted means and confidence intervals (at $95 \%$ ) for the percentage of thrips (adults and nymphs) expelled from asparagus spears by electrical treatments dead or alive, and percentage of thrips (adults and nymphs) killed whether expelled or not.

\begin{tabular}{|c|c|c|c|c|c|c|}
\hline \multicolumn{2}{|c|}{$\begin{array}{l}\text { Treatment } \\
\text { solution } \\
+/-0.12 \% \\
\mathrm{NaCl} \text { Type }\end{array}$} & $\begin{array}{l}\text { Duration } \\
\text { (minutes) }\end{array}$ & $\begin{array}{l}\text { Current } \\
\text { (A) }\end{array}$ & $\begin{array}{l}\text { Voltage } \\
\text { (V) }\end{array}$ & $\begin{array}{c}\text { Mean \% } \\
\text { expelled } \\
\text { (confidence } \\
\text { intervals) }\end{array}$ & $\begin{array}{c}\text { Mean \% } \\
\text { killed } \\
\text { (confidence } \\
\text { intervals) }\end{array}$ \\
\hline 1 - & Ultrasound $^{\mathrm{a}}$ & 2 & NA & NA & $0.0(\mathrm{na})$ & $21.3(12.2-34.4)$ \\
\hline 2 - & Ultrasound $^{\mathrm{a}}$ & 4 & NA & NA & $6.5(1.9-19.5)$ & $29.0(17.2-44.7)$ \\
\hline $3-$ & Ultrasound $^{\mathrm{a}}$ & 8 & NA & NA & $7.0(2.1-21.1)$ & $31.6(18.8-48.0)$ \\
\hline 4 - & Ultrasound $^{\mathrm{b}}$ & 2 & NA & NA & $4.6(1.1-16.7)$ & $25.8(14.9-40.8)$ \\
\hline $5-$ & Ultrasound $^{\mathrm{b}}$ & 4 & NA & NA & $1.7(0.2-17.0)$ & $29.3(17.1-45.6)$ \\
\hline $6-$ & Ultrasound $^{\mathrm{b}}$ & 8 & NA & NA & $3.6(0.7-18.0)$ & $20.0(9.9-36.2)$ \\
\hline 7 - & Energiser $^{\mathrm{c}}$ & 2 & NA & 7700 & $1.9(0.2-18.4)$ & $26.4(14.4-43.4)$ \\
\hline $8-$ & Energiser $^{c}$ & 4 & NA & 7700 & $2.7(0.5-13.9)$ & $32.9(21.1-47.3)$ \\
\hline $9-$ & Energiser $^{c}$ & 8 & NA & 7700 & $7.1(2.4-19.2)$ & $34.3(22.0-49.1)$ \\
\hline $10-$ & Energiser $^{\mathrm{d}}$ & 2 & NA & 5500 & $6.7(2.0-20.1)$ & $40.0(26.0-55.9)$ \\
\hline $11-$ & Energiser $^{\mathrm{d}}$ & 4 & NA & 5500 & $4.9(1.5-15.3)$ & $27.9(17.3-41.6)$ \\
\hline $12-$ & Energiser $^{\mathrm{d}}$ & 8 & NA & 5500 & $8.2(2.8-21.8)$ & $32.8(20.1-48.6)$ \\
\hline $13+$ & DC & 2 & 0.5 & $25-50$ & $2.5(0.4-12.6)$ & $34.6(23.0-48.3)$ \\
\hline $14+$ & DC & 4 & 0.5 & $25-50$ & $7.1(2.9-16.5)$ & $29.9(19.9-42.3)$ \\
\hline $15+$ & DC & 8 & 0.5 & $25-50$ & $6.2(2.1-16.8)$ & $43.8(31.0-57.4)$ \\
\hline $16+$ & DC & 2 & 1.5 & $70-90$ & $3.0(0.5-15.0)$ & $37.3(24.4-52.4)$ \\
\hline $17+$ & DC & 4 & 1.5 & $70-90$ & $4.1(1.0-15.1)$ & $37.0(24.6-51.4)$ \\
\hline $18+$ & DC & 8 & 1.5 & $70-90$ & $5.8(1.7-17.8)$ & $34.8(22.4-49.7)$ \\
\hline $19+$ & DC & 2 & 2.5 & $120-140$ & $4.9(1.2-17.9)$ & $34.4(21.4-50.3)$ \\
\hline $20+$ & DC & 4 & 2.5 & $120-140$ & $8.8(2.2-29.7)$ & $35.3(18.6-56.6)$ \\
\hline $21+$ & DC & 8 & 2.5 & $120-140$ & $5.7(1.4-20.3)$ & $30.2(17.3-47.2)$ \\
\hline $22+$ & $\mathrm{AC}$ & 2 & 0.5 & $40-50$ & $6.9(2.6-17.2)$ & $36.8(25.3-50.0)$ \\
\hline $23+$ & $\mathrm{AC}$ & 4 & 0.5 & $40-50$ & $5.4(1.6-16.7)$ & $25.7(15.3-39.8)$ \\
\hline $24+$ & $\mathrm{AC}$ & 8 & 0.5 & $40-50$ & $6.2(2.1-16.8)$ & $25.9(15.9-39.4)$ \\
\hline $25+$ & $\mathrm{AC}$ & 2 & 1.5 & $70-100$ & $23.2(13.1-37.7)$ & $50.7(36.4-64.9)$ \\
\hline $26+$ & $\mathrm{AC}$ & 4 & 1.5 & $70-100$ & $8.0(2.4-23.6)$ & $58.3(40.7-74.1)$ \\
\hline $27+$ & $\mathrm{AC}$ & 8 & 1.5 & $70-100$ & $12.5(5.1-27.7)$ & $41.1(26.5-57.4)$ \\
\hline $28+$ & $\mathrm{AC}$ & 2 & 2.5 & $120-160$ & $16.2(8.0-30.1)$ & $35.3(22.7-50.3)$ \\
\hline $29+$ & $\mathrm{AC}$ & 4 & 2.5 & $120-160$ & $7.1(2.4-19.2)$ & $37.1(24.5-51.9)$ \\
\hline $30+$ & $\mathrm{AC}$ & 8 & 2.5 & $120-160$ & $5.5(1.3-19.7)$ & $32.7(19.5-49.5)$ \\
\hline $31+$ & Control & & & & & \\
\hline & (untreated) & 8 & - & - & $6.5(2.2-17.6)$ & $33.8(22.1-47.8)$ \\
\hline $32-$ & Control & & & & & \\
\hline & (untreated) & 8 & - & - & 0.0 (na) & $33.3(21.2-48.2)$ \\
\hline
\end{tabular}

\footnotetext{
${ }^{\mathrm{a}}$ Ultrasound Sonicor

${ }^{\mathrm{b}}$ Ultrasound Braun

${ }^{c}$ Energiser Galagher

${ }^{\mathrm{d}}$ Energiser Speedrite

NA Not applicable

(na) Not applicable owing to absence of response
} 
In the second experiment, the chemical treatments, Y-14258 with $60 \%$ of thrips expelled, was significantly better than the other treatments (Table 2). Fatty acids with $27 \%$ of thrips expelled were not significantly different from each other, but were better than the control treatment which expelled only $12 \%$ of the thrips. Y-14258, at $85 \%$ mortality also killed significantly more thrips than the others. Defender and the untreated control did not differ significantly from each other, averaging only $38 \%$ of thrips killed. Veggi-wash, at $60 \%$ provided an intermediate level of thrip mortality.

TABLE 2: Experiment 2 (March 1997). Predicted means and confidence intervals (at $95 \%$ ) by chemical treatments for the percentage of thrips (adults and nymphs) expelled from asparagus spears dead or alive, and percentage of thrips (adults and nymphs) killed, whether expelled or not.

\begin{tabular}{lcccc}
\hline $\begin{array}{l}\text { Treatment } \\
\text { rate }\end{array}$ & $\begin{array}{c}\text { Mean \% } \\
\text { expelled }\end{array}$ & $\begin{array}{c}\text { Confidence } \\
\text { intervals }\end{array}$ & $\begin{array}{c}\text { Mean } \% \\
\text { killed }\end{array}$ & $\begin{array}{c}\text { Confidence } \\
\text { intervals }\end{array}$ \\
\hline Y-14258 $0.1 \%$ & 60.1 & $(54.7-65.3)$ & 84.5 & $(69.0-93.0)$ \\
Veggi-wash 0.05\% & 27.2 & $(23.3-31.4)$ & 59.9 & $(49.8-69.3)$ \\
Defender 0.1\% & 27.1 & $(22.8-31.8)$ & 32.1 & $(22.6-43.3)$ \\
Control (untreated) & 11.8 & $(8.8-15.6)$ & 43.1 & $(33.0-53.7)$ \\
\hline
\end{tabular}

\section{DISCUSSION}

We have been unable to establish an effective method for killing thrips with an electric current. No differences existed between the AC and DC treatments in our trial, although a comparison between AC and DC applied fields revealed differences in lysing of bacteria when high voltage electric fields were used (Johnstone and Bodger 1996).

We subsequently found that the voltage / $\mathrm{cm}$ was probably not high enough (P. Bodger pers. comm.). This was caused in part by laying the spears perpendicular to the electrodes.

Electrodes made of metal sheeting had to be replaced by carbon fibre when electrolysis was noticed during the short treatments. Sodium chloride had to be used in order to prevent electrical heating of the electrolyte solution. A current of 2.5 amperes applied for more than 8 minutes produced damage to spears when the water temperature reached $40^{\circ} \mathrm{C}$. Temperatures in our experiment never exceeded $32^{\circ} \mathrm{C}$ after 8 minutes.

Although experiments in the past have shown that liquid does not easily penetrate the bracts, it was assumed that some current must have passed through the spear and expelled the thrips from the spear because a separate experiment showed that a spear is a conductor when placed in between the electrodes of an electric fence energiser.

These disinfestation methods could be applied to any produce, such as vegetables which are washed in water, before being sold.

ECNZs best idea award 1996, a water purifier, is based on the use of high voltage. This invention has potential applications in horticulture where short electrical pulses may kill insects, mites and probably fungi. Electric fields of up to $15-30 \mathrm{kV} / \mathrm{cm}$ by either impulse or steady state AC/DC could be tested (P. Bodger pers. comm.).

The flushing effect of Y-14258 was obtained without aeration or agitation procedures which might improve its results. There was a 10-fold difference in the density of thrips between the two experiments, and the equivalent controls. The higher thrip density found in the spears used for the chemical treatments may have contributed to the higher success rate of these treatments. Expulsion of thrips is preferable to killing thrips. In several of our experiments there were significant numbers of dead thrips even in control spears. This would potentially lead to problems for the canning industry unless the dead thrips are removed, e.g. by aeration.

None of the electrical or ultrasound treatments significantly affected thrips numbers expelled from spears, or thrips survival. Y-14258 significantly reduced thrips numbers 
on spears. It may be possible to reconfigure the electrical equipment to improve efficacy but present knowledge indicates that the most useful approach to disinfestation lies in improved washing methods.

\section{ACKNOWLEDGEMENTS}

The authors gratefully acknowledge assistance, advice and comments from Pat Bodger (Canterbury University), Udo von Mulert ( Massey University), Mike Arnold (IRL), Alan Dixon and Barry Olsen (Levin Research Centre). The Gallagher Group is gratefully acknowledged for loan of the electric fence energiser. Thanks also to VeggiWash New Zealand for supplying us with Veggi-wash, and Robin Gaskin, NZ Forest Research Institute, for the supply of Y-14258.

\section{REFERENCES}

Carpenter, A., 1987. Postharvest fumigation of fresh asparagus with dichlorvos. Proc. 40th N.Z. Weed and Pest Control Conf:: 71-74.

Carpenter, A., 1995. Implementation of controlled atmosphere disinfestation of export asparagus. Proc. N.Z. 48th Plant Prot.Conf.: 318-321.

Corrigan, V.K. and Carpenter, A., 1993. Effects of treatment with elevated carbon dioxide levels on the sensory quality of asparagus. N.Z. J. Crop Hort. Sci. 21:349357.

Genstat 5, 1993. Release 3 Reference Manual, Genstat 5 Committee, Clarendon Press, Oxford. Green, K. and Mound, L.A., 1994. An extension to the insect fauna of Heard Island. Polar Record 30: 131-132.

Jamieson, R.D. and Bodger, P.S., 1988. The fields associated with overhead transmission lines and their effects on earthworms. Pp 11. IPENZ Conference, New Plymouth.

Johnstone, P.T. and Bodger, P.S., 1996. Liquid disinfestation using high voltage. Pp 5 .Third NZ Conference Postgraduate students in engineering and technology. Dep. of Electrical and Electronic Engineering. University of Canterbury. Christchurch 12 July 1996.

Mound, L.A. and Walker, A.K., 1981. Terebrantia (Insecta: Thysanoptera). Fauna of N.Z. 1: 55.

Nelson, S.O., 1996. Review and assessment of radio frequency and microwave energy for stored grain insect control. Trans. ASAE 39(4): 1475-1484.

Pickens, L.G., Jaworski, J., Kovac, B. and Mills, G.D., 1994. Traps and baits for flies (Diptera) on Pacific islands. J. Med. Entomol. 31(6): 828-832.

Pradzynska, A., 1982. The suitability of ultrasound for controlling stored pest. PraceNaukowe Institutu, Roslin. 24(1): 77-90.

Rohitha, B.H., Gaskin, R.E., Hartley, T. and Karl, A.K., 1992. Evaluation of Silwet L77 for postharvest disinfestation of thrip in asparagus. Proc. 45th N.Z. Plant Prot. Conf: : 17-20.

Sharma, D. and Singh, S., 1994. Effects of electric shock on red flour beetle Triboliumcastaneum (Herbst) - a new approach for controlling stored grain insect pests. J. Insect Sci. 7(2): 148-149.

van Epenhuijsen, C.W. and Wright, S., 1994. A comparison of expulsion methods for thrips and aphids from asparagus spears.Proc. 47th N.Z. Plant Prot.Conf: 193-195.

Waller, J.B., 1990. Insecticidal soaps for post harvest control of thrips in asparagus.Proc. 43rd N.Z. Weed and Pest Control Conf.: 60-62.

Watson, R.N. and Townsend, R.J.,1981. Invertebrate pests on asparagus in Waikato. Proc. 34th N.Z. Weed and Pest Control Conf: : 70-75.

Watson, D.B., 1988. The bouncing of Drosophila melanogaster in power frequency electric fields. N.Z. Entomologist 11: 21-24. 